CHAPTER

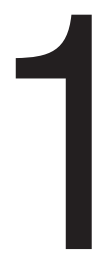

\title{
Cognition and Innovation:
} A Framework and
Invitation to Explore

Kristian J. Sund, Robert J. Galavan and Stefano Brusoni

\begin{abstract}
In this brief introduction, we reflect on the diversity of studies connecting cognition to innovation and the enormous potential that exists for further research. Research streams on cognition in organizations, innovation in organizations, and intra- and entrepreneurship have developed in parallel over the past decades, with frequent touchpoints, notably in terms of theories of cognition informing studies on the processes of innovation and creativity. Cognition theories have thus been considered as micro-foundations of many theories of innovation. Here, we outline the many ways that theories of cognition can yield insights for studies of innovation and discuss the contributions of chapters comprising this third volume of New Horizons in Managerial and Organizational Cognition.
\end{abstract}

Keywords: Biases; creativity; innovation; managerial and organizational cognition; micro-foundations; sense making

Cognition and Innovation

New Horizons in Managerial and Organizational Cognition, Volume 3, 1-11

Copyright (C) 2018 by Emerald Publishing Limited

All rights of reproduction in any form reserved

doi:10.1108/978-1-78769-431-620181001 


\section{Advances in the Study of Cognition}

The study of cognition in and around organizations has advanced considerably over the past 30 years. Taking inspiration from earlier studies of social psychology, organizational and management scholars laid the foundations during the 1980s and into the 1990s for the modern domain of managerial and organizational cognition (MOC) (Walsh, 1995). What emerged was a new view of strategic decision-making that complemented the dominant industry and resource-based views. The knowledge-based view (Grant, 1996; Nonaka \& Takeuchi, 1995) also emerged around this time, but where the unit of analysis in this view is knowledge or information, the processes that lead to or interfere with the creation of knowledge are the realm of MOC studies. The knowledge-based view paved the way for the study of how innovation emerges and spreads. Similarly, the cognitive perspective paved the way for the study of how the individual and shared knowledge structures in organizations are formed and disseminated, and how decisions about what and how to innovate are shaped by the way we think (Glynn, 1996).

The early focus of MOC studies centered on theories of interpretation, according to which managers are "information workers” (McCall \& Kaplan, 1985; Sund, 2015), collecting, handling, and interpreting information from and about the external environment on behalf of the organization (Daft \& Weick, 1984), often under conditions of uncertainty (Huff, Milliken, Hodgkinson, Galavan, \& Sund, 2016; Milliken, 1987, 1990; Sund, 2013, 2015). Such information processing is guided by and creates constructs defined as knowledge structures, mental maps, templates (Walsh, 1995), and schema (Bartunek, 1984). Empirical work in this tradition has focused on revealing and analyzing subjects' explicit representations of knowledge, through methods such as repertory grid analysis, interviews-based taxonomic mapping, and causal mapping (e.g., Eden \& Spender, 1998; Fiol \& Huff, 1992; Hodgkinson \& Healey, 2008; Huff, 1990; Walsh, 1995). Common to such methods is the focus on "conscious" and "cold" cognition (Hodgkinson \& Healey, 2011; Hodgkinson, Sund, \& Galavan, 2018), that is, rational thoughts of which we are aware and can process in the absence of emotion.

Over the past two decades, studies of both hot cognition that is, cognition under conditions of high affect - and automatic, unconscious cognition have emerged in organizational research. These have extended our understanding of the role 
of cognition in organizations and decision-making. Informed by dual-process theory, we now see studies examining how the aspects of our thinking that we do not entirely control or are not entirely aware of, influence our decisions (e.g., Chaiken \& Trope, 1999; Epstein, 1994; Kahneman, 2011; Sloman, 1996; Smith \& DeCoster, 2000). Studies of, for example, subconscious goals, implicit attitudes, and implicit affect, and so on have broadened our understanding of human decision-making and shown it to be more complicated than we previously imagined (Hodgkinson et al., 2018). New empirical research methods such as those offered by neuroscience (e.g., Massaro, 2018; Laureiro-Martinez, 2018; Laureiro-Martinez, Brusoni, Canessa, \& Zollo, 2015), or agent-based modeling (e.g., Healey, Bleda, \& Querbes, 2018; Miller, 2015) can now complement more traditional interview methods (e.g., Vuori, 2018), experimental methods (e.g., Reypens \& Levine, 2018), and survey methods (e.g., Sund, 2016), in opening up the potential to study emotions and unconscious biases in decision-making, including in studies of innovation.

\section{Intersections Between Cognition and Innovation}

The study of innovation, that by some has been defined as "a new idea" (Van de Ven, 1986, p. 591) and by others as "the successful exploitation of new ideas" (Adams, Bessant, \& Phelps, 2006, p. 22), is in itself not new. The concept of innovation has over time become ubiquitous and pervasive, to the point that, in various review articles scoping the literature on innovation, the term has been called a buzzword (Hidalgo \& Albors, 2008) and the body of literature has been criticized for being inconsistent in its operationalization of key constructs such as the degree of innovation (Garcia \& Calantone, 2002). Such criticism notwithstanding, there are today some widely accepted categories of innovation that can help us structure the field, and contextualize findings. The most typical ones are degree of innovation, type of innovation, level of analysis, and process stage.

While there has been some debate about how to clearly differentiate between degrees of innovation, innovations are commonly categorized as either incremental or radical, or somewhere in between. It is also understood that novelty can be new 
to the firm, new to the industry, or new to the world (Ahuja \& Morris Lampert, 2001). How such newness, or innovativeness, is conceived and measured varies enormously across studies. Christensen's (1997) related categorization of sustaining versus disruptive innovation has regained interest recently, thanks to a mass media and industry focus on digitalization trends. The second very common categorization concerns innovation type, where typical categories include product, service, process, techni$\mathrm{cal} /$ technological, administrative, or business model innovation. The third and fourth categorizations can be thought of as the level of analysis, typically categorized as individual level, team level, organizational level, or industry level, and in the many studies looking at innovation as a process, the actual stage in this process, for example, initiation stage, idea generation stage, adoption stage, or implementation stage (Gopalakrishnan \& Damanpour, 1997).

Closer to the aims of this volume, the interplay of cognition and innovation has been at the center of a long and distinguished tradition at the interface between behavioral and social analyses, not least since the landmark work of March and Simon (1958). They managed to seamlessly interweave the social and behavioral elements of cognition, which subsequently separated into distinct conversations.

On the behavioral side, Nelson and Winter (1982) developed an evolutionary theory of the innovating organization built on the notion of "routine" as quasi-genetic material that provides foundations to both stability and change. On this basis, a new paradigm of research in strategy emerged based on the notion of search (e.g., Levinthal, 1997) and problem-solving (e.g., Nickerson \& Zenger, 2004). Similarly, growing interest went in the direction of exploring issues related to attention processes and mechanisms related to the ability of switching across different learning strategies (e.g., Laureiro et al., 2015; Laureiro \& Brusoni, 2018). The discussion about attention is particularly important because it provides a bridge between social and behavioral approaches to cognition and innovation.

Ocasio (1997) developed parts of the discussion opened up by March and Simon (1958) who had given attention a central role in their approach, an element that fell under the radar for many years. Ocasio built on the tradition of organizational sociology and institutional logics to give the concept of organizational attention flesh, bones, and strategic relevance. In parallel, the concept of routine was also being modernized and 
reintegrated into the organizational context where it belongs by the work of Martha Feldman (2000), among many others. While routines came to be accepted as the tangible manifestations of organizational cognitive abilities and skills, the discussion about frames and identity also developed in ways very much consistent with the idea that organizations are institutions moved by socio-cognitive processes embedded in work processes, structures, and routines. Kaplan (2008) developed this line of work looking at how different cognitive frames compete for primacy in organizations. Tripsas (2009) looked at identity as a major factor that explains which decisions firms take (or not) when exploring different and alternative technological trajectories.

\section{The Contributions in this Volume}

There is by now a rich, although still fairly small, literature studying innovation through socio-cognitive lenses (e.g., Kaplan \& Tripsas, 2008). For example, it has been documented how a shared understanding of the existing business model directs the way executives perceive new ideas for business models in incumbent firms (Sund, Villarroel, \& Bogers, 2014; Sund, Bogers, Villarroel, \& Foss, 2016). Or that it is a combination of cognition and emotion that leads groups to adopt or not process innovations in large firms (Choi, Sung, Lee, \& Cho, 2011). Or that due to incongruence with existing schemata, innovation originating outside the firm leads managers to search for information on opportunities or threats (Greve \& Taylor, 2000). These, and the many other studies that have been carried out over the years may appear to point in all sorts of directions. However, combining the ideas of cognitive dual-process with the various categorizations of innovation discussed earlier, provides us with a robust structure or framework for exploring the many contexts and research questions that could be found at the intersection of cognition and innovation. This is illustrated in Fig. 1.

The studies in this collection all contribute, in their own ways, to this discussion. Some extend it in new directions, some add new building blocks to it. For example, one might wish to study how conscious, cold (emotion-independent) cognition affects the implementation stage of a new business model. In such a case, multiple theories of cognition could provide relevant insights. An example is found in Snihur, Thomas, and 


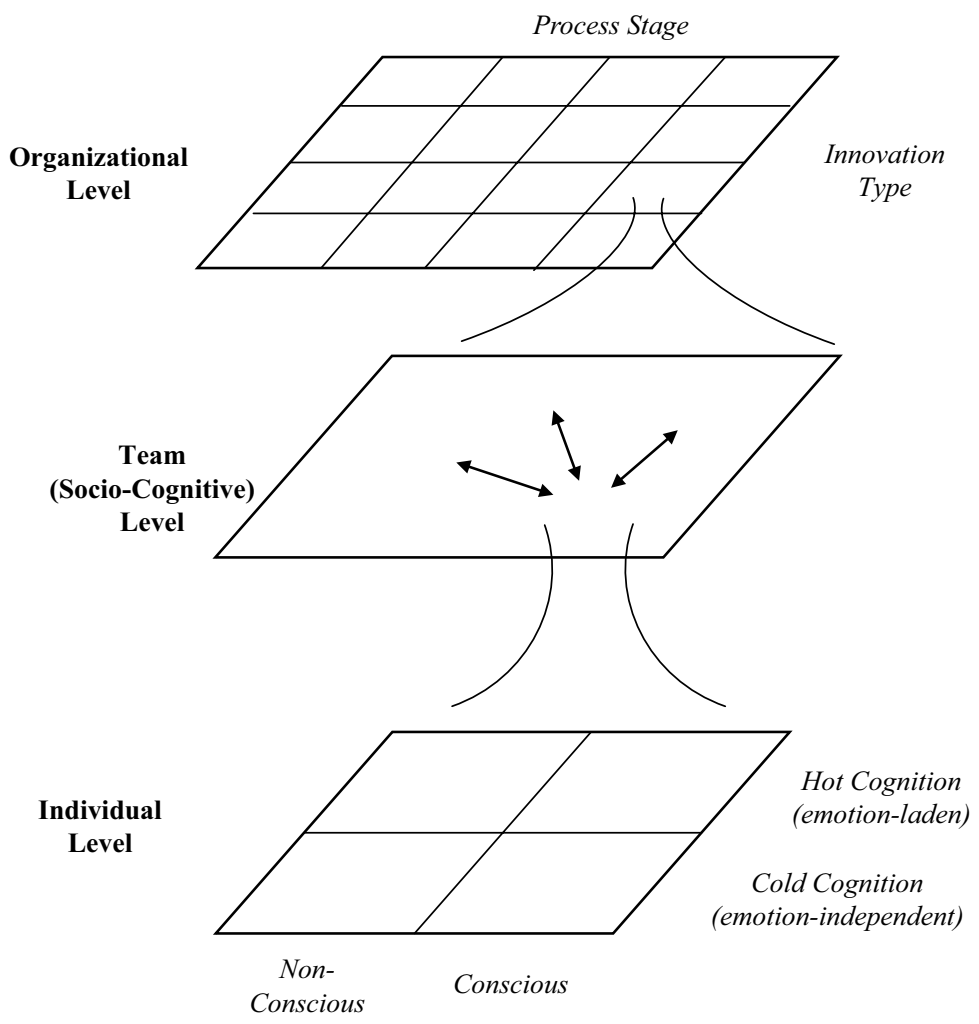

Fig. 1: Framework for the Study of Cognition and Innovation.

Burgelman's (2018) study in this volume, in which they examine how framing can constitute a strategic process that enables business model innovators to shape new ecosystems, involving a number of organizations.

Socio-cognitive processes often occur at the group or team level within the organization, in which case theoretical development may need to consider just how individual-level cognition constructs affect team processes. For example, Zaman, Mount, Pitsis, O'Connor, and Dean (2018) in this volume examine the implementation of a new technology among hospital workers (a form of process innovation), illustrating the role of interactive framing in the social process of adoption and diffusion of the innovation.

Over time, the discussion about innovation has been linked to that of leadership. For example, in this volume, Mahdad, Bogers, Piccaluga, and Di Minin (2018) look at how leadership enables iterative cycles of sense making and sense giving in 
collaborative contexts at the interface between university and industry. Mammassis and Schmid (2018), also in this volume, look instead at the role of power in the context of innovation and change. They build on individual level studies of power (a concept vastly underexploited in the innovation and cognition literature) to discuss how paradoxical leadership plays an important moderating factor on the negative relationship between power asymmetries and team performance.

The chapters by Zagorac and Marxt (2018) and Biehl, Fehre, and Tietze (2018) go back instead to the analysis of the sources of innovation, to reframe (conceptually the former and empirically the latter) this long and distinguished conversation. They do so relying on the attention-based view of the firm and on complementarities with the rich and vast literature on entrepreneurship and opportunity recognition. Biehl et al. (2018) also explore the potential of new, computer-enabled text analysis techniques to provide evidence about their reasoning.

Finally, the chapter by von Krogh, Geilinger, and Rechsteiner (2018) sheds light on one of the great unknowns in the innovation and cognition literature: ethics. In their discussion, they build on practice approaches to organizing to explore how communities and groups deal with the varying requirements of formal and informal practices, and which moral dilemmas occur at their interface.

\section{An Invitation to Explore}

This volume of New Horizons in Managerial and Organizational Cognition cannot illustrate all possible contexts of the presented framework, but we hope it gives sufficient exposure to the topic to encourage pushing the boundaries and exploring further. We extend an invitation to both the MOC and innovation management communities to embrace the theoretical and methodological opportunities that now exist for the study of cognition, in order to explore just how our thinking affects the way we develop ideas and turn them into sustainable businesses and business practices. The various chapters comprising this volume cover diverse topics such as framing in business models, cognitive mechanisms in entrepreneurial opportunity identification, paradoxical leadership and the role of management attention in radical product innovation. We hope that this collection will inspire many others. 


\section{References}

Adams, R., Bessant, J., \& Phelps, R. (2006). Innovation management measurement: A review. International Journal of Management Reviews, 8(1), 21-47.

Ahuja, G., \& Morris Lampert, C. (2001). Entrepreneurship in the large corporation: A longitudinal study of how established firms create breakthrough inventions. Strategic Management Journal, 22(6-7), 521-543.

Bartunek, J. M. (1984). Changing interpretive schemes and organizational restructuring: The example of a religious order. Administrative Science Quarterly, 29, 355-372.

Biehl, E., Fehre, K., \& Tietze, M. (2018). The relationship between demand-pull attention and radical product innovation - Evidence through computer-aided text analysis. In K. J. Sund, R. J. Galavan, \& S. Brusoni (Eds.), Cognition and innovation. Bingley: Emerald Publishing.

Chaiken, S., \& Trope, Y. (Eds.). (1999). Dual-process theories in social psychology. New York, NY: Guilford Press.

Choi, J. N., Sung, S. Y., Lee, K., \& Cho, D. S. (2011). Balancing cognition and emotion: Innovation implementation as a function of cognitive appraisal and emotional reactions toward innovation. Journal of Organizational Behavior, 32(1), 107-124.

Christensen, C. (1997). Innovators dilemma. Boston, MA: Harvard Business School Press.

Daft, R. L., \& Weick, K. E. (1984). Toward a model of organizations as interpretation systems. Academy of Management Review, 9(2), 284-295.

Eden, C. and Spender, J.-C. (Eds.) (1998). Managerial and organizational cognition: Theory, methods and research. London: Sage.

Epstein, S. (1994). Integration of the cognitive and the psychodynamic unconscious. American Psychologist, 49, 709-724.

Feldman, M. S. (2000). Organizational routines as a source of continuous change. Organization Science, 11(6), 611-629.

Fiol, C. M., \& Huff, A. S. (1992). Maps for managers. Where are we? Where do we go from Here? Journal of Management Studies, 29, 267-285.

Garcia, R., \& Calantone, R. (2002). A critical look at technological innovation typology and innovativeness terminology: A literature review. Journal of Product Innovation Management, 19(2), 110-132.

Glynn, M. A. (1996). Innovative genius: A framework for relating individual and organizational intelligences to innovation. Academy of Management Review, 21(4), 1081-1111.

Gopalakrishnan, S., \& Damanpour, F. (1997). A review of innovation research in economics, sociology and technology management. Omega, 25(1), 15-28.

Grant, R. M. (1996). Toward a knowledge - Based theory of the firm. Strategic Management Journal, 17(S2), 109-122.

Greve, H. R., \& Taylor, A. (2000). Innovations as catalysts for organizational change: Shifts in organizational cognition and search. Administrative Science Quarterly, 45(1), 54-80. 
Healey, M. P., Bleda, M., \& Querbes, A. (2018). Modeling affect and cognition: Opportunities and challenges for managerial and organizational cognition. In R. J. Galavan, K. J. Sund, \& G. P. Hodgkinson (Eds.), Methodological challenges and advances in managerial and organizational cognition (New Horizons in Managerial and Organizational Cognition, Vol. 2, pp. 23-57). Bingley: Emerald Publishing. Hidalgo, A., \& Albors, J. (2008). Innovation management techniques and tools: A review from theory and practice. R\&D Management, 38(2), 113-127.

Hodgkinson, G. P., \& Healey, M. P. (2008). Cognition in organizations. Annual Review of Psychology, 59, 387-417.

Hodgkinson, G. P., \& Healey, M. P. (2011). Psychological foundations of dynamic capabilities: Reflexion and reflection in strategic management. Strategic Management Journal, 32, 1500-1516.

Hodgkinson, G. P., Sund, K. J., \& Galavan, R. J. (2018). Exploring methods in managerial and organizational cognition: Advances, controversies, and contributions. In R. J. Galavan, K. J. Sund, \& G. P. Hodgkinson (Eds.), Methodological challenges and advances in managerial and organizational cognition (pp. 1-22). Bingley: Emerald Publishing.

Huff, A. S. (Ed.). (1990). Mapping strategic thought. Chichester: John Wiley \& Sons. Huff, A. S., Milliken, F. J., Hodgkinson, G. P., Galavan, R. J., \& Sund, K. J. (2016). A conversation on uncertainty in managerial and organizational cognition. In K. J. Sund, R. J. Galavan, \& A. S. Huff (Eds.), Uncertainty and strategic decision making (pp. 1-31). Bingley: Emerald Publishing.

Kahneman, D. (2011). Thinking, fast and slow. London: Allen Lane.

Kaplan, S. (2008). Framing contests: Strategy making under uncertainty. Organization Science, 19(5), 729-752.

Kaplan, S., \& Tripsas, M. (2008). Thinking about technology: Applying a cognitive lens to technical change. Research Policy, 37(5), 790-805.

Laureiro-Martinez, D. (2018). How do managers really think? Using think aloud and fMRI to take a closer look at managerial cognition. In R. J. Galavan, K. J. Sund, \& G. P. Hodgkinson (Eds.), Methodological challenges and advances in managerial and organizational cognition (pp. 279-314). Bingley: Emerald Publishing.

Laureiro-Martínez, D., \& Brusoni, S. (2018). Cognitive flexibility and adaptive decision-making: Evidence from a laboratory study of expert decision makers. Strategic Management Journal, 39(4), 1031-1058.

Laureiro-Martinez, D., Brusoni, S., Canessa, N., \& Zollo, M. (2015). Understanding the exploration-exploitation dilemma: An fMRI study of attention control and decision-making performance. Strategic Management. Journal, 36, 319-338.

Levinthal, D. A. (1997). Adaptation on rugged landscapes. Management Science, 43(7), 934-950.

March, J. G., \& Simon, H. A. (1958). Organizations. New York, NY: John Wiley \& Sons.

Mahdad, M., Bogers, M., Piccaluga, A., \& Di Minin, A. (2018). Exploring the organization of university-industry joint laboratories: A leadership perspective. In K. J. Sund, R. J. Galavan, \& S. Brusoni (Eds.), Cognition and innovation. Bingley: Emerald Publishing. 
Mammassis, C. S., \& Schmid, P. C. (2018). The role of power asymmetry and paradoxical leadership in software development team agility. In K. J. Sund, R. J. Galavan, \& S. Brusoni (Eds.), Cognition and innovation. Bingley: Emerald Publishing.

Massaro, S. (2018). Neuroscience methods: A framework for managerial and organizational cognition. In R. J. Galavan, K. J. Sund, \& G. P. Hodgkinson (Eds.), Methodological challenges and advances in managerial and organizational cognition (pp. 241-278). Bingley: Emerald Publishing.

McCall, M. W., \& Kaplan, R. E. (1985). Whatever it takes: Decision makers at work. Englewood Cliffs, NJ: Prentice Hall.

Miller, K. D. (2015). Agent-based modeling and organization studies: A critical realist perspective. Organization Studies, 36(2), 175-196.

Milliken, F. J. (1987). Three types of perceived uncertainty about the environment: State, effect, and response uncertainty. Academy of Management Review, 12(1), 133-143.

Milliken, F. J. (1990). Perceiving and interpreting environmental change: An examination of college administrators' interpretation of changing demographics. Academy of Management Journal, 33(1), 42-63.

Nelson, R. R., \& Winter, S. G. (1982). An evolutionary theory of economic change. Cambridge, MA: Harvard University Press.

Nickerson, J. A., \& Zenger, T. R. (2004). A knowledge-based theory of the firm The problem-solving perspective. Organization Science, 15(6), 617-632.

Nonaka, I., \& Takeuchi, H. (1995). The knowledge-creating company: How Japanese companies create the dynamics of innovation. Oxford: Oxford University Press.

Ocasio, W. (1997). Towards an attention-based view of the firm. Strategic Management Journal, 18(S1), 187-206.

Reypens, C. \& Levine, S. S. (2018). To grasp cognition in action, combine behavioral experiments with protocol analysis. In R. J. Galavan, K. J. Sund, \& G. P. Hodgkinson (Eds.), Methodological challenges and advances in managerial and organizational cognition (pp. 123-146). Bingley: Emerald Publishing.

Sloman, S. A. (1996). The empirical case for two systems of reasoning. Psychological Bulletin, 119, 3-22.

Smith, E. R., \& DeCoster, J. (2000). Dual-process models in social and cognitive psychology: Conceptual integration and links to underlying memory systems. Personality and Social Psychology Review, 4, 108-131.

Snihur, Y., Thomas, L. D. W., \& Burgelman, R. A. (2018). The performative power of words: How business model innovators use framing for strategic advantage. In K. J. Sund, R. J. Galavan, \& S. Brusoni (Eds.), Cognition and innovation. Bingley: Emerald Publishing.

Sund, K. J. (2013). Scanning, perceived uncertainty, and the interpretation of trends: A study of hotel directors' interpretation of demographic change. International Journal of Hospitality Management, 33, 294-303.

Sund, K. J. (2015). Revisiting organizational interpretation and three types of uncertainty. International Journal of Organizational Analysis, 23(4), 588-605.

Sund, K. J. (2016). A test of perceptual accuracy and overconfidence in a strategic issue context. In K. J. Sund, R. Galavan, \& A. Huff (Eds.), Uncertainty and strategic decision making (pp. 101-126). Bingley: Emerald Publishing. 
Sund, K. J., Bogers, M., Villarroel, J. A., \& Foss, N. (2016). Managing tensions between new and existing business models. MIT Sloan Management Review, 57(4), 8 .

Sund, K. J., Villarroel, J. A., \& Bogers, M. (2014). Organizational aspects of business model innovation: The case of the European postal industry. In Academy of management proceedings (Vol. 2014, No. 1, p. 11099). NY: Academy of Management.

Tripsas, M. (2009). Technology, identity, and inertia through the lens of "The Digital Photography Company.” Organization Science, 20(2), 441-460.

Van de Ven, A. H. (1986). Central problems in the management of innovation. Management Science, 32(5), 590-607.

von Krogh, G., Geilinger, N., \& Rechsteiner, L. (2018). The moral dilemma of caring versus ruling: An examination of the ethical turn in practices. In K. J. Sund, R. J. Galavan, \& S. Brusoni (Eds.), Cognition and innovation. Bingley: Emerald Publishing.

Vuori, T. O. (2018). An open-ended interview approach for studying cognition and emotion in organizations. In R. J. Galavan, K. J. Sund, \& G. P. Hodgkinson (Eds.), Methodological challenges and advances in managerial and organizational cognition (pp. 59-71). Bingley: Emerald Publishing.

Walsh, J. P. (1995). Managerial and organizational cognition: Notes from a trip down memory lane. Organization Science, 6, 280-321.

Zaman, T., Mount, M., Pitsis, T., O’Connor, R., \& Dean, S. (2018). A sociocognitive model of innovation adoption and implementation. In K. J. Sund, R. J. Galavan, \& S. Brusoni (Eds.), Cognition and innovation. Bingley: Emerald Publishing.

Zagorac-Uremovic, Z. \& Marxt, C. (2018). Cognitive processes of entrepreneurial opportunity identification: Towards a holistic understanding of the micromechanisms. In K J. Sund, R. J. Galavan, \& S. Brusoni (Eds.), Cognition and innovation. Bingley: Emerald Publishing. 